INTERNATIONAL JOURNAL OF RESEARCHES IN BIOSCIENCES, AGRICULTURE \& TECHNOLOGY (C) VISHWASHANTI MULTIPURPOSE SOCIETY (Global Peace Multipurpose Society) R. No. MH-659/13(N) www.vmsindia.org

\title{
CHEMICAL DEPOSITION OF LARGE AREA SILVER SUPHIDE FILMS
}

\section{Dhumure S.S.}

Ramkrishna Paramhansa Mahavidyalaya, Osmanabad (M.S.) India Gmail: indalkar.supriya7@gmail.com

\begin{abstract}
In this communication, we report on the chemical deposition of large area $\left(\approx 50 \mathrm{~cm}^{2}\right)$ of $\mathrm{Ag}_{2} \mathrm{~S}$ films from an acidic medium using thioacetamide as a sulpher source. The effect of deposition temperature from $8^{\circ} \mathrm{C}$ to $55^{\circ} \mathrm{C}$ was studied. The electrical resistivity microstructure and XRD of the films have studied. Photoelectrochemical cells showed that, the films are $\mathrm{n}$ type and photoactive in nature.
\end{abstract}

Keywords: Chemical deposition, Thioacetamide, Photoelectrochemical

\section{Introduction:}

Mangalam etal (1) have reported on chemical deposition of $\mathrm{Ag}_{2} \mathrm{~S}$ films from alkaline medium at room temperature using thiourea as $\mathrm{Ag}_{2} \mathrm{~S}$ films from an acidic medium. The films of $\mathrm{Ag}_{2} \mathrm{~S}$ have been chemically deposited onto glass, stainless steel and titanium substrates, using thioacetamide as a sulphur source. The preparative parameters have been optimized. The reaction mechanism for deposition from acidic medium have been proposed. Thin, reflecting adhesive and polycrystalline $\mathrm{Ag}_{2} \mathrm{~S}$ films were studied. In this paper, the electrical resistivity, XRD microstructure, photelectrochemical studies of these films are reported.

\section{Experimental:}

Aqueous solution (15 $\mathrm{ml}$ of $0.1 \mathrm{M})$ silver nitrate and $(15 \mathrm{ml}$ of $0.5 \mathrm{M})$ thioacetamide were mixed together in a beaker. To it, glass substrates were immersed, after being attached to a holder and stirred continuously during deposition. The $\mathrm{pH}$ of the solution was 2.5. The solution colour was changed to blakesh and after 30 mins. films were taken out of the bath, washed with double distilled water and preserved in an air tight container. The films were adhesive uniform to the substrates. In this study, for the deposition at $8^{\circ} \mathrm{C}$ the solution were cooled down at $8^{\circ} \mathrm{C}$ with ice bath, before mixing, the reaction mixture was placed in a constant bath temperature maintained at $8^{\circ} \mathrm{C}$ for 30 mins. A study of the optical absorption of the films were carried out using UV-VIS-NIR spectrophotometer. The structure of the films was determined by X-ray diffraction pattern using $\mathrm{CuK} \propto$ radiation with Philips pw 1710 diffractometer. The activation energies of the films were determined by measuring the dark conductivity from 300 to $575 \mathrm{~K}$ using two probe method using pressure contact.

\section{Results and Discussion:}

Silver sulphide films have been deposited from acidic medium, using thioacetamide as a sulphur releasing source. The reaction mechanism is proposed as follows.

$4 \mathrm{AgNO}_{3}+2 \mathrm{CH}_{3} \mathrm{C} \quad \mathrm{S} \quad \mathrm{NH}_{2}+4 \mathrm{H}^{+} \rightarrow \mathrm{Ag}_{2} \mathrm{~S}+$ $2 \mathrm{CH}_{3} \mathrm{CONH}_{2}+4 \mathrm{NO}_{2}+2 \mathrm{H}_{2} \mathrm{O}$...(1)

The film quality was improved at $27^{\circ} \mathrm{C}$, the film thickness was increased with decreasing temperature. Fig. 1 shows $\mathrm{Ag}_{2} \mathrm{~S}$ films deposited at $8^{\circ} \mathrm{C}$ bath temperature. The films were uniform and thin.

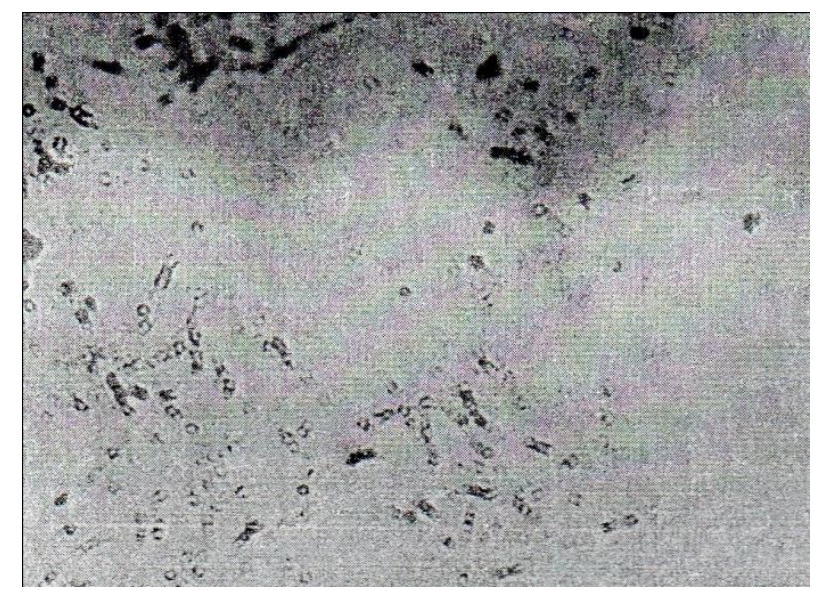

Fig. $1 \mathrm{Ag}_{2} \mathrm{~S}$ films deposited at $8^{\circ} \mathrm{C} \times 375$ (magnification)

We have studied the electrical resistivity of the $\mathrm{Ag}_{2} \mathrm{~S}$ films deposited in the range 8 to $55^{\circ} \mathrm{C}$. It was found that, resistivity for the 
deposition at $8^{\circ} \mathrm{C}$ bath temperature is of the order $1-2 \times 10^{5} \mathrm{ohm} \mathrm{cm}$. Fig. 2 shows the plot of $\log \rho \quad \operatorname{vs}_{\frac{I}{T}}$ for the $\mathrm{Ag}_{2} \mathrm{~S}$ films deposited at $8^{\circ} \mathrm{C}$ and $27^{\circ} \mathrm{C}$. The plots shows two regions corresponding to low and high temperature regions. The value of activation energies in both the regions are $0.069 \mathrm{eV}$ and $0.37 \mathrm{eV}$ at $8^{\circ} \mathrm{C}$ and $0.10 \mathrm{ev}$ and $0.24 \mathrm{ev}$ at $27^{\circ} \mathrm{C}$ respectively. $\mathrm{X}$-ray diffraction pattern were taken using pw1710 diffractometer to examine the $\mathrm{Ag}_{2} \mathrm{~S}$ film. It shows that, the films are polycrystalline in nature. Figure 3 shows X-ray diffraction pattern of annealed $\mathrm{Ag}_{2} \mathrm{~S}$ films at $200^{\circ} \mathrm{C}$. The observed ' $\mathrm{d}$ ' values of $\mathrm{Ag}_{2} \mathrm{~S}$ are in good agreement with standard 'd' values taken from the ASTM Diffraction Data File are given below.

\section{Observed d values}

\subsection{2}

2.573

Standard d values

2.434

2.836

2.583

2.440

2.421

2.412

2.383

2.379

2.072

1.962

1.963

1.556

Optical absorption of $\mathrm{Ag}_{2} \mathrm{~S}$ films was studied in the wavelength range of 900 and 2000 $\mathrm{nm}$ for the film. The absorption coefficient ' $\alpha$ ' was found to be of the order of $10^{4}$ to $10^{5}$ $\mathrm{cm}^{-1}$ above the band gap region.

The $\mathrm{Ag}_{2} \mathrm{~S}$ films were $\mathrm{n}$ type in nature and showed photovoltaic activity in a photoelectrochemical cell formed with $1 \mathrm{M}$ $\left(\mathrm{NaOH}-\mathrm{Na}_{2} \mathrm{~S}-\mathrm{S}\right)$ electrolyte. The $\mathrm{ISC} \cong 0.1$ $\mathrm{mA} / \mathrm{cm}^{2}$ and $\mathrm{Voc} \cong 100 \mathrm{mV}$ has been obtained at $100 \mathrm{~mW} / \mathrm{cm}^{2}$ illumination intensity.

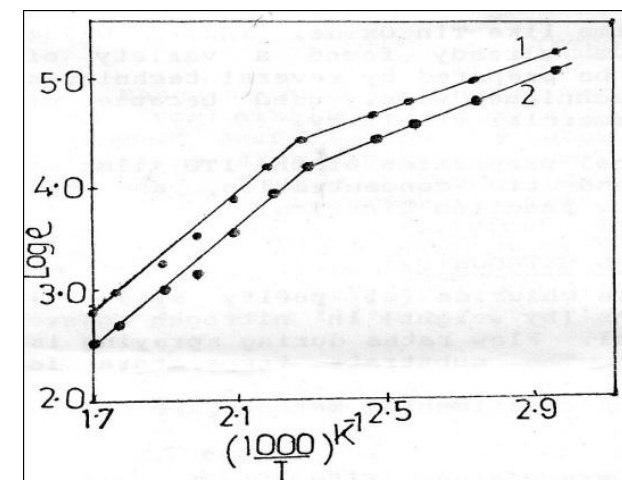

Fig. $2 \log \rho$ vs $\frac{I}{T}$ for the $\mathrm{Ag}_{2} \mathrm{~S}$ films deposited at $8^{\circ} \mathrm{C}$ and $27^{\circ} \mathrm{C}$

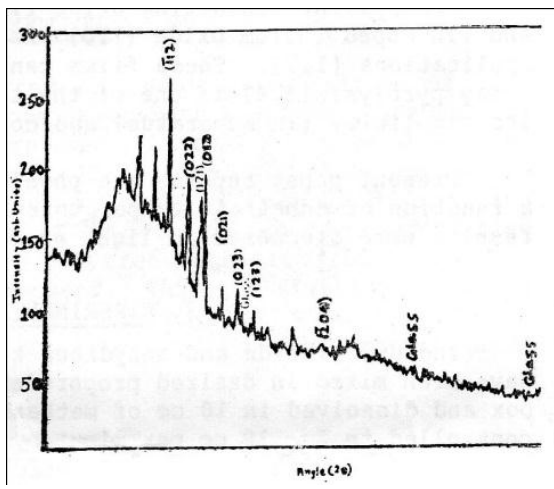

Fig. 3 X-ray diffraction pattern of annealed $\mathrm{Ag}_{2} \mathrm{~S}$ films at $200^{\circ} \mathrm{C}$

\section{References:}

M. J. Mangalam etal. Ind. J. of pure and App.Phys. 7 (1969) 628.

S.S. Dhumure and C.D. Lokhande 1991 Mater.Chem.and Phys. 2732

Lokhande C.D. 1990 J.Phys. D: Appl. Phys. 231703

Dhumure S.S. and Lokhande C.D. 1991 Mater.Chem.Phys. 28141 